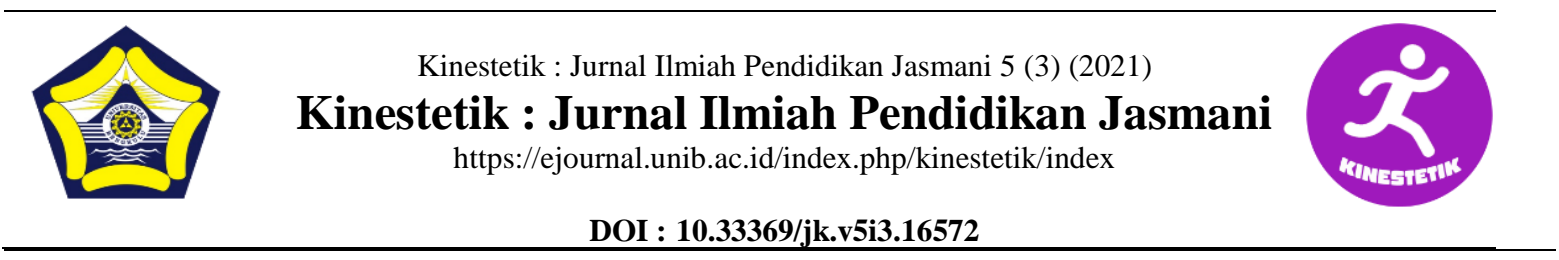

\title{
TRAINING KNEE TUCK JUMP IN ORDER TO INCREASETHE TIME TO DRILL THE BALL THAN THE SPLIT JUMP
}

\author{
Yovinianus Mbede Wea ${ }^{1 *}$ \\ ${ }^{1}$ Physical Education Health and Recreation, Teacher Training and EducationofCitra Bakti \\ College, NTT, Indonesia
}

\section{Article Info}

Article History :

Received : June 2021

Revised : September 2021

Accepted : September 2021

Available online : September 2021

Keywords:

Travel Time, Dribbling, Knee Tuck Jump, Split Jump

\section{Abstract}

The capability is necessary not only to exercise but also in situations of physical activity. To achieve this necessary exercise continuous and systematic so easily trained athletes in learning a new movement, such as the knee tuck jump exercise and split jump. The research was conducted with the pretest-posttest control group design in the second semester students PJKR STKIP study program of Citra Bakti, with a sample of 28 people who were divided into two groups and each group numbered 14 people, which are 14 people are control group and 14 people are experimental group. Both groups were given different training carried out for 6 weeks with a frequency of exercise three times a week. The study Results were analyzed descriptively on the variants age, height, weight, body mass index in the two groups for which data was taken before sampling in the implementation of the training. Test using the Shapiro-Wilk normality test and homogeneity test with Leven's tests. Test average travel time to dribble tested with t-paired with a value of $\mathrm{p}<0.05$, with a mean Group 1 knee tuck jump before treatment $15.178 \pm 0517$ seconds and after treatment $10.969 \pm 0.778$ seconds with a value of $p=0.000$. Whereas in Group II split jump with a mean $15.179 \pm 0.462$ before training and after training 11.563 seconds \pm 0.562 seconds with a value of $p=0.000$. Results of the effect of changes in travel time difference dribble after training on knee tuck jump Group I and Group II after training jump split-tested by an independent $\mathrm{t}$ with nilap $\mathrm{p}<0.05$, and $\mathrm{p}$ values in this study $\mathrm{p}=0.029$ by a margin increase on group I knee tuck jump 4.209 and the difference in group II split jump 3.616 percentage increase in Group I with a knee tuck jump $27.73 \%$ and the percentage of Group II split jump $23.82 \%$. It showed that the group I knee tuck jump and jump the second group split equally give the effect of an increase ( $\mathrm{p}<0.05)$. However, the increase in Group I of knee tuck jump better than Group II split jump in terms of travel time. Suggested was intensified in the knee tuck jump training in the training process, athlete recruitment and implementation of motion activity, because it gives the effect of an increase.

\begin{tabular}{llr}
\hline Corresponding address & : STKIP Citra Bakti, jln. Trans-bajawa- & ISSN 2685-6514 (Online) \\
& ende, Malanuza, Golewa, Ngada, Flores & NTT, 86461 \\
$*$ Corresponding email & : yovinianusmw@ gmail.com & ISSN 2477-331X (Print)
\end{tabular}




\section{INTRODUCTION}

Football is a sport game that is quite popular in the community, so that the game of football is widely favored by the community, ranging from children to adults, both by rural and urban communities. The development of football in Indonesia is quite encouraging when seen from the number of children playing soccer activities, especially events such as the National Student Sports Olympiad (O2SN), or other championships as a vehicle for channeling the talents and interests of students. in the school environment. This game is a complex game because it is not easy for everyone to do. Knowledge of basic or advanced techniques is required to be able to master or play well.

Techniques that are classified as foundation are the most basic or lowest level of training menus. These technical exercises are aimed at developing the basic skills required by all players, but this training menu is not intended to deal with actual match conditions. Building a solid foundation is a must. Just like people build a house, the stronger the foundation, the bigger and varied the size and shape of the building that can be erected on it. So the basic skills are clearly needed by the players. According to (Suwarno Kr., 2001) techniques with the ball are as follows: Some of the basic techniques with the ball in playing football that a football player needs to have are kicking the ball, receiving the ball, dribbling, grabbing the ball. the ball (tackling), throw-in (throw in), and technique of goal keeping: defensive and offensive (technique of goal keeping: defensive and offensive). According to (Sardjono O. Santoso, 1995) the basic techniques with the ball in the game of football are all movements using the ball that are carried out in playing football. From some of the opinions above, it can be concluded that the understanding of basic techniques with the ball in the game of football is all movements with the ball that are needed in playing football in developing maximum performance.

Some of the physical components needed in soccer are biological components, namely in the form of food, namely adequate calories, fluids and protein (Ismaryati, 2006). While the biomotor components that are considered are coordination, flexibility, speed, strength, agility. In performance sports, physical condition needs to be considered, because the benefits can result in a better level of fitness(Powers. SK, Doddy, SL and Jackson, 2011)Thus, the player must be supported by the ability to train in relation to the explosive power of the leg muscles. The explosive power of the leg muscles is influenced by the ability of the muscles to do explosions (sudden and strong) and is greatly influenced by the speed of muscle reaction.(Paul, 2018).

The components of the physical condition in dribbling are: strength, endurance, muscular power, speed, flexibility, agility, coordination, balance, accuracy, reactions that will affect the explosive power of the leg muscles.(Sajoto,2002). FurthermoreSajoto, (1995)The explosive power of the leg muscles occurs due to the shortening and lengthening of the muscles in the upper and lower limbs which are supported by the force of the leg muscles so that they can affect the maximum speed. Increasing the speed of dribbling is a complex process in which there are several different aspects and work to support each other so that great leg power is achieved.

Knee jumps are fast and strong physical exercises. This exercise is done by kneeling and holding your palms under the ground (Fakhruddin, Shadiqin, \& Irianto, 2020). The knee tuck jump exercise emphasizes the exercise of the legs by jumping as high as it is done with the legs that are close together and bending the fleas to touch the hands in front of the chest so that it is expected to have an effect on strength and explosive power which in turn can support the running 
speed of the soccer player.(Brotherhood Abduh1, 2020).

Knee tuck jump and split jump training can increase leg power, which will affect flexibility, joint components, muscle and tendon strength, muscle work balance. (Menegpora, 2005). To support this movement, of course, it requires maximum leg muscle power, so that a soccer player can move in all directions with maximum speed. This is due to the maximum joint movement(Yoda, 2006).

The formulations in this study are: 1) Can knee tuck jump training increase the travel time for dribbling the fourth semester students of the PJKR STKIP Citra Bakti study program? 1) Can split jump training increase the travel time of dribbling for the fourth semester students of the PJKR STKIP Citra Bakti study program? 3) Does knee tuckjum training improve dribbling travel time more than split jumps in semester IV students of the STKIP Citra Bakti PJKR Study Program?

The objectives of this research are:

To prove the knee tuck jump training on the travel time of dribbling the fourth semester students of the STKIP Citra Bakti PJKR Study Program?

2) To prove split jump training to the travel time of dribbling in the fourth semester students of the PJKR STKIP Citra Bakti Study program. 3) To prove that knee tuck jump training increases the travel time of dribbling more than split jump training in semester IV students of the PJKR STKIP Citra Study program Service.

\section{METHODS}

This study used an experimental method applied to the fourth semester students of the PJKR STKIP Citra Bakti Study Program with the experimental Randomized Pre and Post Test Control Group Design.(Poccok, 2008).

\section{Participants}

The population of this study were 50 semester students of the PJKR STKIP Citra Bakti study program. The research sample was obtained from a population that met the following criteria: 1) Male gender. 2) 17-25 years old, good physical fitness category. 3) height $160-180 \mathrm{~cm} .4$ ) weight $50-70 \mathrm{~kg}$.

\section{Sampling Procedures}

The research was conducted with the pretest-posttest control group design in the second semester students PJKR STKIP study program of Citra Bakti, with a sample of 28 people who were divided into two groups and each group numbered 14 people. Both groups were given different training carried out for 6 weeks with a frequency of exercise three times a week.

\section{Materials and Apparatus}

Material which was using in this research was the ball in order to giving students doing the drill.

\section{Procedures}

Both groups were given different training carried out for 6 weeks with a frequency of exercise three times a week.

\section{Data Analysis}

Description Analysis to analyze the subject data such as: height, weight, age, body mass index for which data have been taken. Normality test aims to determine the distribution of data for each treatment group from the two training groups. The data in this study were on a normal scale. By using the Shapiro-Wilk Test. The significant value is greater than 0.05 ( $p>$ 0.05 ), then the data is normally distributed. Homogeneity Test Aims to determine the variation of data with a limit of significance or level of confidence used is the Levene test. The significance value is greater than $0.05(\mathrm{p}>0.05)$, then the data is homogeneous. 


\section{Comparison Test}

The comparative test between the two groups before and after training using the paired t-test aims to analyze the mean increase in changes in training on the knee tuck jump and split jump. Test of increasing travel time speed of dribbling after knee tuck jump and split jump training in both groups was tested by $\mathrm{t}$ indenpendent. The limit of significance used is 0.05 .

Table 1.

Test Results of the Difference in the Effects of Increased Travel Time in Dribbling Between Groups After Group I Training Knee tuck jump and after Group II training split jump

\begin{tabular}{llll}
\hline Variable & $\begin{array}{l}\text { Travel time to dribble } \\
\text { (seconds) }\end{array}$ \\
\cline { 2 - 3 } & $\begin{array}{l}\text { Mean } \quad \pm \quad \mathrm{P} \\
\text { SB }\end{array}$ & \\
\hline $\begin{array}{l}\text { Ex. Knee } \\
\text { tuck }\end{array}$ & $10.968 \quad \pm$ & \\
jump & 0.778 & & \\
& $11.562 \quad \pm$ & 0.029 \\
$\begin{array}{l}\text { Ex. Split } \\
\text { Jump }\end{array}$ & 0.561 & & \\
\hline
\end{tabular}

\section{DISCUSSION}

The results of the normality of the travel time to dribble before and after training using the Shapiro Wilk test showed that the $p$ value before training in Group I was 0.212 and after training the value was 0.621. Whereas in Group II before training the value of 0.177 and after training the $p$ value of 0.252 . Thus the two groups $p>0.05$. This shows that both groups are said to be normal.

Homogeneity test shows the $\mathrm{p}$ value in both groups before training and after training $\mathrm{p}=0.290$. Thus $\mathrm{p}>0.05$ so it is said that the two groups of data distribution are the same. The different test of travel time before training in the two groups using t-paired showed a value of $p$ $<0.05$. The test results for the mean travel time of dribbling before and after the two groups showed $\mathrm{p}<0.05$. The difference

\section{RESULTS}

The results of the research conducted on the fourth semester students of the PJKR STKIP Citra Bakti Study Program obtained the following data: data on the characteristics of research subjects, research environment data, results of travel time to dribble in both Group 1 (knee tuckjump) and Group 2 (split jump). ).

test for the mean travel time of dribbling in the two groups before and after the training showed a difference in improvement in Group I of 4.209 and in Group II of 3.616 with a p-value in both groups of $p, 0.05$. The test results of increasing the travel time travel time using t-indenpen den showed $p=0.002$ and the results in this study $\mathrm{p}<0.05$ with the percentage increase in Group I $27.73 \%$ and in Group II 23, 82\% This indicates an increase in the two different groups meaningfully. The difference in final results is caused by differences in the ability of the two groups and the treatment given and training 3-5 times a week can increase the travel time to dribble.(Nala, 2001).

The occurrence of hypertropy is due to an increase in the number of myofibrils in each muscle fiber. The occurrence of neural adaptation is indicated by an increase in one's technique and skill level(Sukadiyanto, 2005).

Speed is a combination of agility which is very important, by having these two biomotor components, a soccer player will be able to move in all directions in a fast dribbling and will be able to break through the opponent's defense. Knee tuck jump training is a plyometrics movement designed to move hip muscles, limbs and special muscles(I Wayan Just Andika, 2014).

From a physiological point of view, the knee tuck jump and split jump training has an effect on explosive power, 
which can be seen from changes in muscle performance, increased muscle mass and muscle function. With each movement of the muscles, they contract and relax. Relating to the notion of leg muscles, which is part of the lower limb that allows movement to move from one place to another, from this moving movement it will cause continuous muscle contraction and relaxation. A regular and targeted training program on an ongoing basis will result in adjustments to increasing physical conditions.(Radlife and Farentinus, 2000).

Knee tuck jump and split jump training is a part of plyometrics that can increase strength and speed or what is called explosive power (Nala, 2001). Strength in question is a component of physical condition that concerns an athlete's problem in using his muscles to receive a load during a certain working time 1 . The muscles that are affected by knee tuck jump training are: gluteus, gastronemius, quadriceps, hamstring and hip flexors, while the muscles are Muscles that are affected by split jump training are: hamstring, gluteus, quadriceps

(Hanafi, 2010) Muscle strength is also the ability of a muscle or group of muscles to do work and withstand loads during work. This is in line with opinion(Years, Training, Tuck, Leg, \& Muscles, nd)If knee tuck jump training is done frequently, the contractions in the leg muscles will also often occur.This also causes muscle contraction to be faster because in this training there is an element of strength when jumping, so the muscle groups that are affected in this training are the thigh, knee, and knee muscles. calf.

With the element of strength in knee tuck jump training, the principle to train explosive power has been fulfilled so that there will be an increase in explosive power. The knee tuck jump training mechanism that emphasizes the maximum height by turning the leg with both thighs folded and jumping up at the same time will affect the strength of the leg muscles which have an impact on the results of agility and speed, while the split jump training which emphasizes the beat of the foot. those who refuse to go up place more emphasis on the level of flexibility(Kanca, 2014). The same thing was confirmed by previous researchersSoeharno, (19993)that the knee tuck jump training emphasizes the explosive power of the leg muscles (strength and speed) so that it will affect the speed in this case the speed of dribbling, while the split jump training emphasizes flexibility. Thus, the knee tuck jump training increases the explosive power of the leg muscles in performing dribbling speed compared to the split jump seen from the muscle elements contained therein.

That the greater the load in carrying out the activity, the more muscles will contract to contract which will affect the results of the velocity of the biomotor components, including the speed and agility of dribbling the ball.

The results of previous studies Harimbawa, et, al. Examined the effect of knee tuck jump and split jump training on increased leg muscle flexibility and power. The results showed that knee tuck jump training emphasizes leg muscle strength, while split jump training emphasizes flexibility. With an increase in the leg muscles it will affect the dribbling time. Thus, the knee tuck jump training increases the travel time of dribbling more than the split jump.

Septo Winarko researched the Difference of the Effect of Plyometricknee tuck jump and squat jump Exercise on Ball Grinding Agility (measured in this study is the travel time of dribbling speed. The final test results show 10.33 seconds of knee tuck jump training and 11 squat jump training 64 seconds This shows that after doing the training the knee tuck jump is better than the split jump seen from the travel time, the speed of the dribble has a different or significant value. 


\section{CONCLUSIONS}

Based on the results of data analysis and discussion, it can be concluded that the research are The knee tuck jump training significantly increased the dribbling time from $15.177 \pm 0.517$ seconds to $10.968 \pm 0.778$ seconds. Split jump training significantly increases dribbling travel time from $15.178 \pm 0.462$ to $11.562 \pm 0.561$. The knee tuck jump training increased the travel time of dribbling more than the split jump with an increase in the knee tuck jump group of 4.209 and the difference in the increase in the split jump group was 3,616 with the percentage increase in the knee tuckjump group of $27.73 \%$ and Group II split jump of $23.82 \%$.

\section{REFERENCES}

Fakhruddin, Shadiqin, A., \& Irianto, T. (2020). The Effect Of Knee Tuck Jump Plyometrics Training On Dollyo Chagi Athlete Taekwondo. 407(Sbicsse 2019), 50-52.

Https://Doi.Org/10.2991/Assehr.K.20021 9.013

Hanafi. (2010). Efektifitas Latihan Beban Dan Latihan Plyometrik Dalam Meningkatkan Kekuatan Otot. Jurnal Ilara, 1 (2): 1-9.

I Wayan Just Andika. (2014). E - Journal Jurnal Ikor Universitas Pendidikan Ganesha Jurusan Ilmu Keolahragaan ( Volume Ii Tahun 2014 ) Pengaruh Pelatihan Knee Tuck Jump Dan Double Leg Bound Universitas Pendidikan Ganesha E - Journal Jurnal Ikor Universitas Pendidikan Ganesha Jurusan. Ii, 1-10.

Ikhwan Abduh1, M. J. S. L. (2020). Efek Latihan Pliometrik Knee Tuck Jump Dan Scissors Jump Terhadap Pendahuluan
Olahraga Merupakan Kegiatan Yang Sistematis Untuk Mendorong, Membina , Rohani Dan Social ( Bangun 2016; Yuliawan 2017; Nopembri Et Al . 2018 ). Pemerintah Berusaha Agar Rakya.

Ismaryati. (2006). Tes Dan Pengukuran. Surakarta: Ghalia Indonesia.

Kanca, I. . (2014). Metode Penelitian Pengajaran Pendidikan Jasmani Dan Olahraga. Singaraja. Universitas Pendidikan Ganesha. Singaraja: Universitas Pendidikan Ganesha.

Menegpora. (2005). Menegpora, 2005. Panduan Penetapan Parameter Tes Pada Pusat Pelatihan Pelajar Dan Sekolah Khusus Olahragawan. Jakarta: Depati Peningkatan Prestasi Iptek Olahraga.

Nala. (2001). Prinsip Pelatihan Fisik Olahraga. Universitas Udayana Denpasar.

Paul, J. (2018). Comparative Effect Of Squat Jump And Split Jump Exercise On Dynamic Balance Among Female Netball Players. (April). Https://Doi.Org/10.15621/Ijphy/2018/V5 i2/170742

Poccok, S. J. (2008). Clinical Trial A Partical Approach. England: :John Wiley \& Sons.

Powers. S.K, Doddy, S.L. And Jackson, E. . (2011). Total Fitness And Welness Media Up Date. Brief Edition. San Fransisco I Benjamin Cumming Pearson. San Fransisco I Benjamin Cumming Pearson.

Sajoto. (2002). Kelanjutan Pembinaan Kondisi Fisik Dalam Olahraga. Semarang.

Sukadiyanto. (2005). Pengantar Teori Dan Metodologi Melatih Fisik. Yogyakarta: Universitas Negeri Yogyakarta. Yogyakarta: Universitas Negeri Yogyakarta.

Suwarno Kr. (2001). Gerakan Dasar Dan Teknik Dasar. Yogyakarta: Pko Fik Uny. Yoda. (2006). Pengantar Pendidikan Sepak Bola. Budi Utomo. 